\title{
Active labour market policy by a profit-maximizing firm
}

Citation for published version (APA):

Gerards, R., Muysken, J., \& Welters, R. A. M. H. M. (2014). Active labour market policy by a profitmaximizing firm. British Journal of Industrial Relations, 52(1), 136-157. https://doi.org/10.1111/j.14678543.2012.00915.x

Document status and date:

Published: 01/03/2014

DOI:

10.1111/j.1467-8543.2012.00915.x

Document Version:

Publisher's PDF, also known as Version of record

Document license:

Taverne

Please check the document version of this publication:

- A submitted manuscript is the version of the article upon submission and before peer-review. There can be important differences between the submitted version and the official published version of record.

People interested in the research are advised to contact the author for the final version of the publication, or visit the DOI to the publisher's website.

- The final author version and the galley proof are versions of the publication after peer review.

- The final published version features the final layout of the paper including the volume, issue and page numbers.

Link to publication

\footnotetext{
General rights rights.

- You may freely distribute the URL identifying the publication in the public portal. please follow below link for the End User Agreement:

www.umlib.nl/taverne-license

Take down policy

If you believe that this document breaches copyright please contact us at:

repository@maastrichtuniversity.nl

providing details and we will investigate your claim.
}

Copyright and moral rights for the publications made accessible in the public portal are retained by the authors and/or other copyright owners and it is a condition of accessing publications that users recognise and abide by the legal requirements associated with these

- Users may download and print one copy of any publication from the public portal for the purpose of private study or research.

- You may not further distribute the material or use it for any profit-making activity or commercial gain

If the publication is distributed under the terms of Article $25 \mathrm{fa}$ of the Dutch Copyright Act, indicated by the "Taverne" license above, 


\title{
Active Labour Market Policy by a Profit-Maximizing Firm
}

\author{
Ruud Gerards, Joan Muysken and \\ Riccardo Welters
}

\begin{abstract}
This article investigates the effectiveness of an employment programme exclusively run by a private sector firm in order to find out whether such a programme can be beneficial to both the participating individuals and the private firm. To answer these questions, we use a unique dataset on a private employment programme covering 23 years of operations and data on 1,000 participating unemployed individuals. Using conservative estimates, we show that a private employment programme is more effective in reintegrating the unemployed than public efforts, while providing tangible benefits to the firm.
\end{abstract}

\section{Introduction}

It is well documented that subsidized private sector employment programmes (SPSEPs), in which the government pays firms to provide experience to unemployed workers, seem to perform relatively well in bringing the unemployed back to work. ${ }^{1}$ This article investigates the effectiveness of a pure private employment programme to find out whether such a programme can also be beneficial for both unemployed workers and firms. We explore this question by analysing the effectiveness of a large Dutch firm's employment programme, based on a unique dataset covering a period of 23 years and data on 1,000 participating persons. We find that this pure private programme performs markedly better than public programmes.

One of the private components that give SPSEPs an advantage over other forms of active labour market policy (ALMP) is that SPSEPs more closely resemble a regular work environment, and hence facilitate the build-up of relevant human capital (Sianesi 2008). Other advantages of private involvement are that participation in an SPSEP works as a positive signal towards

Ruud Gerards and Joan Muysken are at Maastricht University. Riccardo Welters is at James Cook University. 
future employers (Gerfin et al. 2005), and that similarly it is a very direct way of demonstrating one's abilities to employers (Graversen 2004). Although these benefits can be ascribed to private sector involvement, these programmes are still initiated, designed, administrated and evaluated by the public sector. Several aspects of this programme set-up create scope for cream-skimming. First, since these programmes are mostly evaluated based on their post-programme effects, caseworkers have an incentive to select the most employable - who are not always those who stand to benefit most from it (Aakvik et al. 2005). Second, Martin and Swank (2004) show that persuading firms to participate in AMLP entails more than just a wage subsidy, and somewhat related, Martin and Grubb (2001) present results that suggest that firms' participation in these programmes is positively linked to the quality of participants they can expect. Thus, even if caseworkers were able to identify flawlessly those who would benefit most from participation, they would need to think twice before actually selecting them, as these participants might not satisfy the firm's expected quality.

In case of a pure private programme, there is obviously no need to persuade the firm to participate since it is its own program. Hence, the delicate balancing act is no longer required. A pure private programme would still enjoy the advantages already mentioned. In addition, it may be attractive for a firm to run a private ALMP for reasons we will investigate.

The remainder of this article is structured as follows. We elaborate on the programme we study in Section 2. In Section 3, we analyse the outflow data of the programme, and in Section 4 we discuss the performance of the programme. In Section 5, we present a number of benefits for the firm when running a pure private labour market programme. Section 6 concludes.

\section{A private initiative: the Philips Employment Scheme (WGP)}

The unemployment rate in the Netherlands rose dramatically in the early 1980s, peaking at a record high of 10.2 per cent in 1983 (CPB 2009). Among the unemployed were a large number of youngsters, below age 23. This development induced the government and unions to agree on a package of reforms called the Wassenaar Agreement in 1982. An important element of this agreement was an economy-wide reduction in working hours to split the same amount of work into more jobs. However, Philips Electronics, the Dutch multinational known for, among others, its household appliances and lighting products, preferred a different approach to combat unemployment and make its contribution in these times of need. Since it was one of the largest employers in the Netherlands, it was able to implement its own course of action. Instead of reducing working hours, Philips created the 'Youth Work Plan' (YWP). The YWP offered unemployed youngsters one year of work and training with Philips, and had 639 participants by the end of 1983, its inaugural year (van der Bruggen and van Schagen 2001). The YWP ran successfully until 1986, at which time the number of unemployed youth had 
declined substantially. According to van der Bruggen and van Schagen (2001), the apparent success of the YWP led unions to embrace it, which in turn led Philips and the unions to incorporate the YWP into the centralized wage agreement. This meant that part of Philips' wage budget was allocated to the programme. At the same time, the scope of the programme was expanded to include other groups of unemployed; the YWP morphed into the Philips Employment Scheme (WGP). To avoid confusion with the commonly used abbreviation PES for public employment services, we will abbreviate Philips Employment Scheme to 'WGP' in this article (based on 'Werkgelegenheidsplan', the Dutch name of the programme). The basic set-up, however, remained largely unchanged and still entailed one year of full-time employment and training at Philips. Participants receive the legal minimum wage, and the training component's objective is to obtain a vocational qualification, and therefore includes a substantial theoretical component. However, the WGP goes beyond vocational education. It comprises a considerable amount of on-the-job training, and also job counselling services are provided, including job interview training and personal development training. The WGP, therefore, can be considered an ALMP comparable to the SPSEPs mentioned in the introduction.

By design, employment in the WGP is not conflicting with existing (regular) employment at Philips. If there was no WGP, the tasks performed by WGP participants would simply not be performed. Moreover, strict monitoring by independent auditors ensures that the target group of disadvantaged unemployed is indeed reached. Each year, the human resource management (HRM) department of Philips allocates WGP jobs over the various Philips establishments. The main consideration for this allocation is the future job prospects of participants. Since Philips has plants and offices operating in various industrial sectors and regions throughout the Netherlands, the future job prospects differ per region, and subsequently the choice as to which outlets are assigned to open WGP jobs matters (Welters 2005). Due to this regional and sectoral variation, this allocation process turns out to be an interactive process between the central HRM department and local HRM staff. Philips aims a yearly WGP inflow of 1 per cent of the total employment in the company.

Figure 1 shows the number of participants entering the WGP compared with Philips' total employment and unemployment. On average, Philips attains the 1 per cent target, but the inflow varies substantially over time, which several WGP managers attribute to the difficulty to attract suitable candidates during economic upswings. The figure corroborates this finding since the periods in which the 1 per cent target is not attained feature low unemployment.

The data used to construct the figures in this section originate from WGP annual reports from 1987 to 2009 . Table 1 presents summary statistics of the most important variables in this dataset. The most striking feature of the data is the job finding rate of almost 70 per cent measured one year after WGP exit. Judging by this gross measure of effectiveness, the WGP seems to 
FIGURE 1

WGP Inflow.

Based on data from the WGP annual reports.

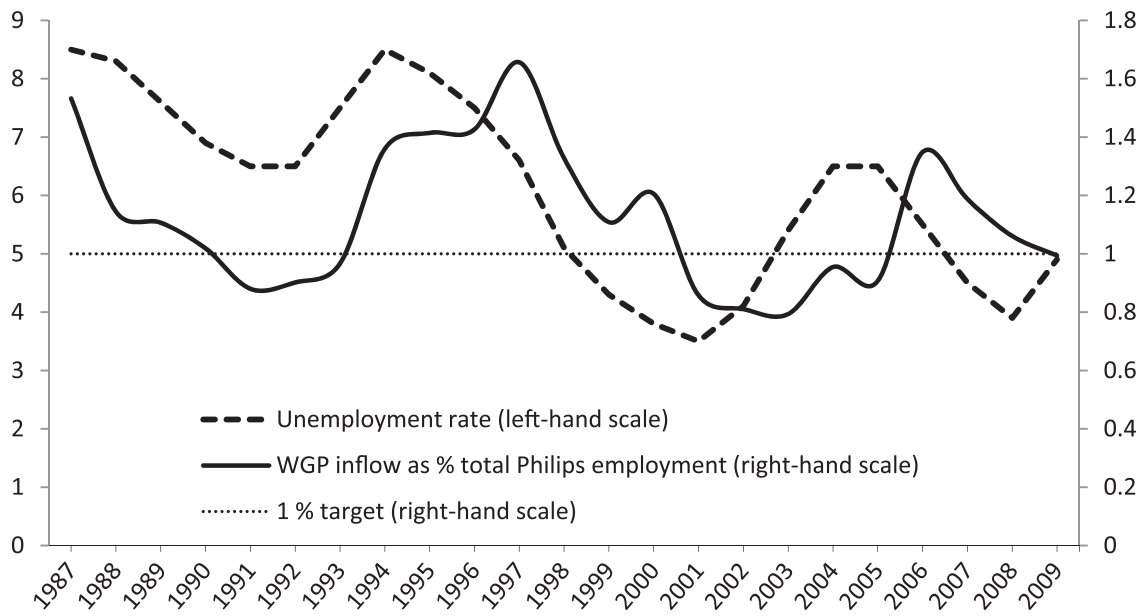

TABLE 1

Summary of Annual Data

\begin{tabular}{lcccc}
\hline Variable $(N=23$ years $)$ & Years & Mean & Min & Max \\
\hline Total employment Philips NL & $1987-2010$ & 36,202 & 14,217 & 70,942 \\
Total inflow & $1987-2009$ & 427 & 143 & 768 \\
\% males in inflow & $1988-2009$ & 57.1 & 38 & 76 \\
Average age of inflow & $1988-2009$ & 31.2 & 23.5 & 35.8 \\
Job finding rate 6 weeks after WGP exit & $1987-2009$ & 60.9 & 40 & 79 \\
Job finding rate 1 year after WGP exit & $1995-2009$ & 69.2 & 50 & 84 \\
\hline
\end{tabular}

perform admirably, but ultimately we need to assess its net effectiveness. This necessitates a more subtle and in-depth analysis of the performance of the WGP. This performance crucially depends on three stages: selection of the participants, treatment and outflow counselling. In the subsequent section, we elaborate on the design of each of these stages.

\section{Selection}

Four selection criteria apply to be eligible to participate in the WGP. First, a candidate must be formally registered as unemployed. ${ }^{2}$ The WGP then explicitly targets those unemployed with the largest distance to the labour market, which is the second criterion: that is, long-term unemployed, early schoolleavers, unemployed from ethnic minorities, refugees, persons with disability and higher-educated persons with weak ties to the labour market. Third, a candidate should have the potential to successfully complete the practical and theoretical training component that is part of the WGP treatment. Philips 
co-operates with public and private sector intermediaries (both paid by government agencies) to find candidates who match these three criteria. It is anticipated that a candidate should possess a certain level of willingness to participate, and this constitutes the fourth criterion, which is tested at the relevant Philips outlet. In principle, all four criteria have to be satisfied.

We compare the characteristics of the inflow into the WGP with the characteristics of the total population of the unemployed in Figures 2 and 3. For Figure 2, we use information from a dataset on about 8,900 WGP participants - see the Appendix for details. The only available information is age, education, gender, and start year and duration of WGP treatment. For Figure 3, we use a different dataset on about 1,000 individuals, described in more detail in Section 2.2 and in the Appendix.

Compared with the total population of unemployed, Figure 2 shows that low-educated unemployed are over-represented in the WGP, and Figure 3 shows that long-term unemployed are generally over-represented in the WGP. This exemplifies that the inflow of the WGP does not represent the a priori - most employable unemployed available.

Additionally, Table 2 provides further evidence of the (un)employability of participants. Until several years ago, the public employment services assigned the unemployed to degrees of employability, where degree one indicated an easily employable person, and degree four a hardly employable person. Table 2 is based on the only available sample of our data that contains this labelling. The participants in this sample have been positioned throughout different Philips outlets between August 2002 and April 2003. Therefore, this sample implicitly includes the efforts of various intermediaries and various Philips floor managers and WGP co-ordinators. Over 90 per cent of the participants in this sample are considered to be 'legitimate' programme

FIGURE 2

Education Level of WGP Inflow Compared with Total Population of Unemployed.

Unemployment data from Statistics Netherlands Labour Force Research (EBB).

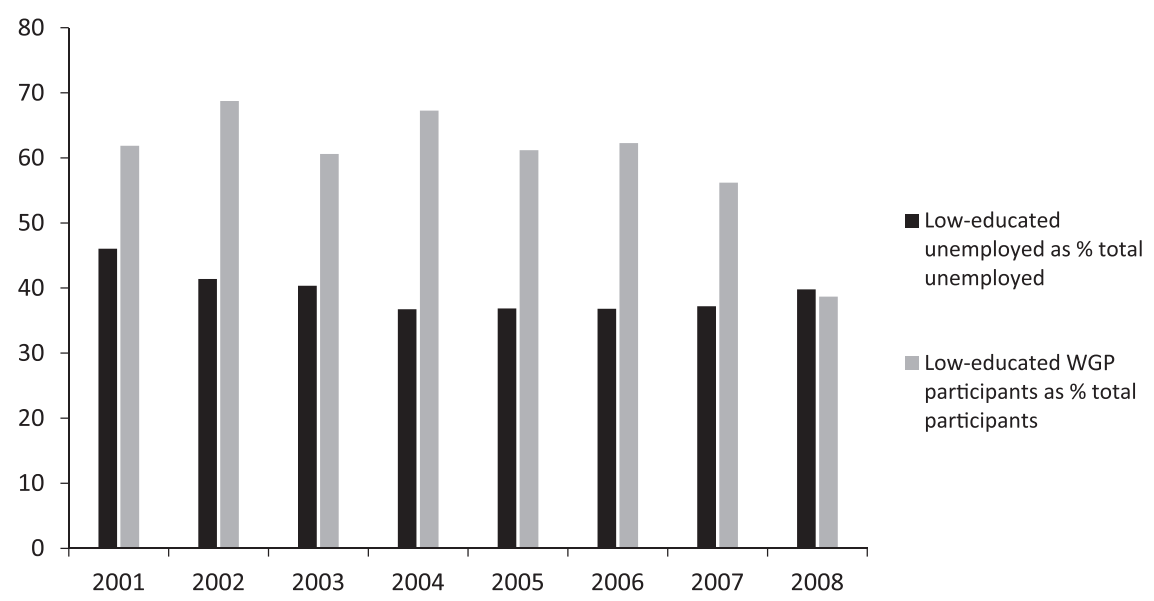

(C) John Wiley \& Sons Ltd/London School of Economics 2012. 
FIGURE 3

Unemployment Duration of WGP Inflow Compared to Total Population of Unemployed.

Unemployment data from Statistics Netherlands Labour Force Research (EBB).

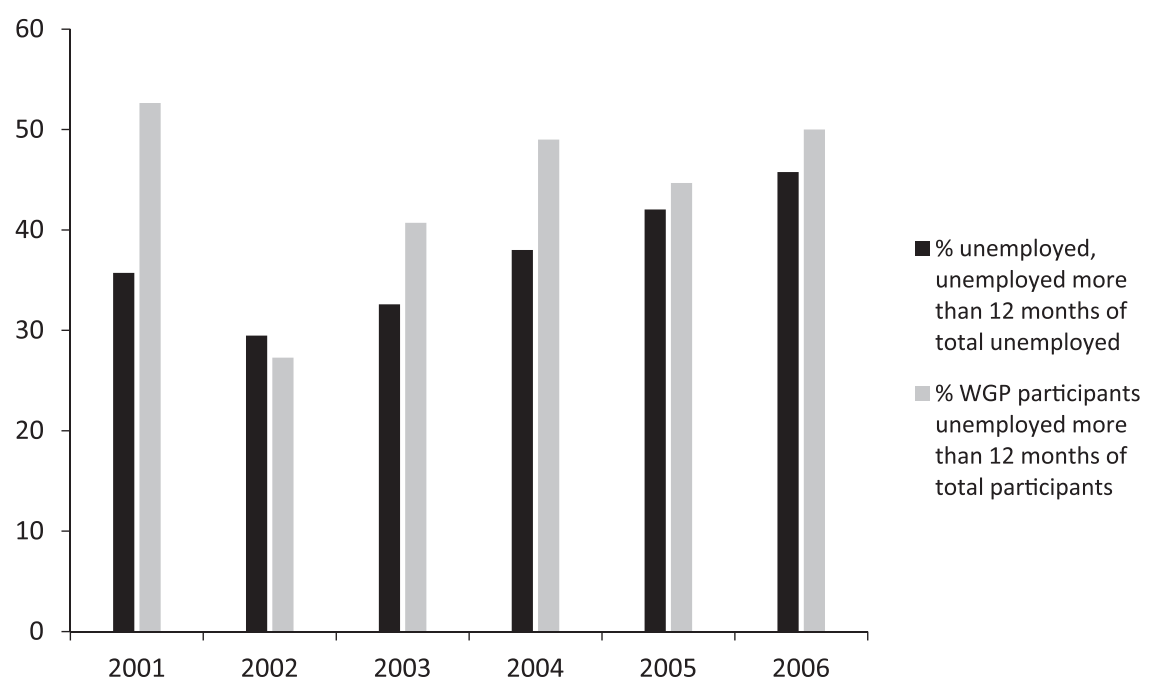

TABLE 2

Employability of WGP Inflow: A Sample of August 2002-April 2003

\begin{tabular}{llccc}
\hline Degree & \multicolumn{1}{c}{ Definition } & In WGP sample & $\%$ & Cum. \\
\hline 4 & $\begin{array}{l}\text { Unemployable } \\
\text { Unemployed with such a distance to the labour } \\
\text { market that job finding chances have been } \\
\text { reduced significantly }\end{array}$ & 10 & 10.9 & 10.9 \\
& $\begin{array}{l}\text { Unemployed who are less easily employable but are } \\
\text { able to find a job within a year with support of } \\
\text { schooling or subsidy }\end{array}$ & 21 & 22.8 & 91.3 \\
$\quad \begin{array}{l}\text { Unemployed who are easily employable and can } \\
\text { find a job without financial support within a } \\
\text { reasonable time span }\end{array}$ & 8 & 8.7 & 100 \\
Total & 92 & 100 & \\
\hline
\end{tabular}

participants (degrees, 2, 3 and 4), and almost 70 per cent of the participants in this sample are considered tough or virtually impossible to reintegrate as they belong to degrees three and four. Less than 9 per cent of the participants are from the most employable segment of unemployed.

A final observation is that the participants of the WGP are relatively young and male when compared with the average unemployed. As we will elaborate in Section 4, this is in favour of their employability.

\section{Treatment and Outflow Counselling}

The treatment in the WGP consists of one year of work experience combined with formal training that leads to a vocational qualification. Since the end 
of the 1990s, half of the WGP participants start with a five-month preprogramme because their initial qualifications are too low to enter the WGP directly. They would not be able to attain the vocational qualification within the standard WGP time frame of one year. After this pre-programme, they enter the WGP proper (van der Bruggen 2004). Many participants are also not able to complete the entire WGP treatment in one year and are offered a 6- or 12-month extension. These developments exemplify the large distance to the labour market of many candidates.

The type of training that a participant receives depends on the nature of the particular WGP job. Many of the WGP participants still complete the Vapro degree, which is a widely recognized qualification in the Dutch process industry. However, due to changes in the labour market and in the qualifications of participants, there has been an increase in the number of participants who complete a degree in other fields, such as administrative, secretarial, and information and communications technology skills. The knowledge and skills acquired during the training are brought into practice on the job. Throughout the entire WGP period, the participant receives regular supervision, counselling and guidance primarily from within Philips, and occasionally also from the intermediary.

Outflow counselling starts three to six months before the end of the WGP period and is provided by the intermediary that proposed the participant for the programme. Specific counselling activities vary but generally include individual job interview training and personal development training. After exiting the WGP, all participants are contacted twice to answer a number of questions about their participation and their current situation. First, six weeks after exiting, the participants are sent a large paper questionnaire, which is completed by, on average, 59 per cent.

One question, asked in this questionnaire, is whether the former WGP participant is currently employed. Since 1995, this question is asked again one year after exiting the WGP, and this time, participants who do not respond to the question in writing are also contacted by telephone. This extra effort helps bring the total response to this question to, on average, 88 per cent. The answers have been aggregated by Philips and were used in the annual reports about the WGP. Figure 4 shows the aggregate job finding rate over the history of the WGP. On average, 60 per cent of the respondents report to be employed when asked six weeks after exiting the WGP, whereas this increases to 70 per cent after one year. On average, 15 per cent of the respondents were employed by Philips at completion of the WGP period, while this figure has varied from 11 per cent to 34 per cent. When asked about their general opinion on their WGP period, on average, 70 per cent of the respondents answer 'satisfied' or 'very satisfied' (on a 5-point scale).

\section{The gross effect of the WGP}

In Section 2, we found that, on average, 70 per cent of participants hold a job when interviewed one year after leaving the WGP. In this section, we take a 
FIGURE 4

Aggregate Job Success of WGP.

Based on annual data from the WGP yearly reports and on unemployment data from Statistics Netherlands.

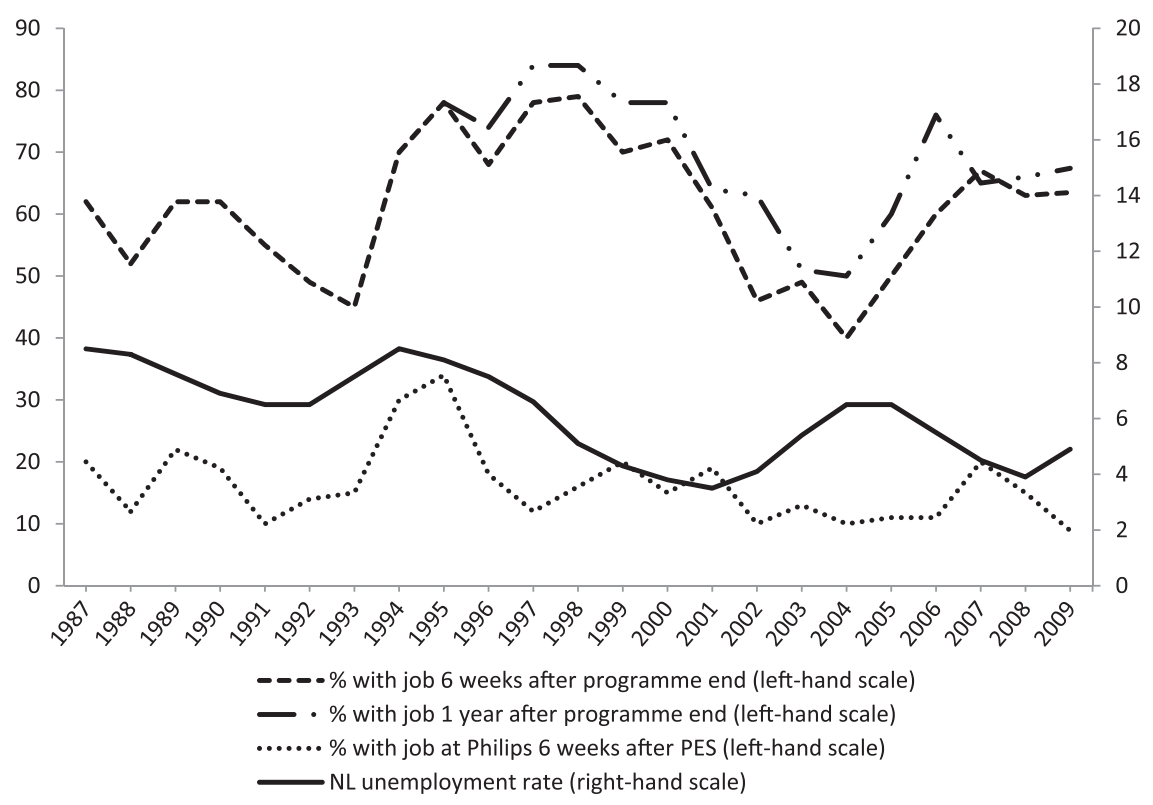

closer look at the WGP to investigate what factors influence its job finding rate and the quality of its participants.

\section{Who Get a Job after the WGP?}

To analyse the determinants of the job finding rate of the WGP participants, we use both aggregate annual data (see Table 1 for a description) and individual questionnaire data. Although the questionnaires have been in use since 1987, and their results are still available in aggregate form, the participants' individual answer sheets are only available for the period 1999-2007 (see the Appendix for more information.). Table 3 presents the results of the two models that shed light on job finding chances after the WGP. The aggregate model uses the job finding rate (six weeks after programme exit, as shown in Figure 4) as dependent variable, and the individual model uses a job finding dummy. Both models show a positive relation between the job finding rate/dummy and unemployment at time of inflow, and a negative relation with unemployment at time of outflow. This second relation suggests that higher unemployment at time of outflow means a lower chance of finding a job. This seems logical as more job seekers compete for the same number of jobs. The first relation indicates that participants who enter the WGP when unemployment is high have a 
TABLE 3

Explaining Participants' Job Finding Chances

\begin{tabular}{|c|c|c|c|c|}
\hline \multirow{2}{*}{$\begin{array}{l}\text { Data used } \\
\text { Period } \\
\text { Regression } \\
\text { Dependent variable } \\
\text { Unemployment at time of inflow }\end{array}$} & \multicolumn{2}{|c|}{$\begin{array}{c}\text { Yearly aggregates } \\
\text { 1988-2007 } \\
\text { OLS } \\
\text { Job finding rate }\end{array}$} & \multicolumn{2}{|c|}{$\begin{array}{c}\text { Individual } \\
\text { 1999-2007 } \\
\text { Probit } \\
\text { Job finding dummy }\end{array}$} \\
\hline & $6.16^{* * *}$ & $(1.77)$ & $0.30^{* * *}$ & $(0.09)$ \\
\hline Unemployment at time of outflow & $-8.52 * * *$ & $(1.75)$ & $-0.50 * * *$ & $(0.09)$ \\
\hline Age & & & $-0.03 * * *$ & $(0.01)$ \\
\hline Gender & & & 0.06 & $(0.08)$ \\
\hline \multicolumn{5}{|l|}{ Prior education: } \\
\hline Average educational attainment $\mathrm{t}^{\mathrm{a}}$ & $0.10 * * *$ & $(0.02)$ & \multirow{2}{*}{\multicolumn{2}{|c|}{ Reference }} \\
\hline Primary school & & & & \\
\hline Low-level vocational/secondary & & & -0.01 & $(0.17)$ \\
\hline Middle-level vocational/secondary & & & -0.03 & $(0.16)$ \\
\hline High-level vocational & & & 0.06 & $(0.18)$ \\
\hline University & & & 0.28 & $(0.20)$ \\
\hline Unemployment status & & & $-0.44 * * *$ & $(0.15)$ \\
\hline \multicolumn{5}{|l|}{ Unemployment duration: } \\
\hline $0-6$ months & & & \multicolumn{2}{|c|}{ Reference } \\
\hline 6-12 months & & & 0.05 & $(0.12)$ \\
\hline 12-24 months & & & -0.13 & $(0.13)$ \\
\hline 2448 months & & & 0.19 & $(0.15)$ \\
\hline $48+$ months & & & -0.05 & $(0.16)$ \\
\hline \multicolumn{5}{|l|}{ If unemployed, what age: } \\
\hline Age $16-30$ & & & \multicolumn{2}{|c|}{ Reference } \\
\hline Age $31-40$ & & & $0.37 * *$ & $(0.14)$ \\
\hline Age $41-50$ & & & 0.33 & $(0.22)$ \\
\hline Age $51+$ & & & 0.26 & $(0.31)$ \\
\hline Constant & -0.28 & $(0.18)$ & $1.70^{* * *}$ & $(0.40)$ \\
\hline$N$ & \multicolumn{2}{|c|}{22 years } & \multicolumn{2}{|c|}{996} \\
\hline$R^{2}$ & \multicolumn{2}{|c|}{0.75} & & \\
\hline Durbin-Watson D-statistic & \multirow{2}{*}{\multicolumn{2}{|c|}{2.21}} & \multirow{2}{*}{\multicolumn{2}{|c|}{$61.35 \%$}} \\
\hline Correctly classified by probit model & & & & \\
\hline
\end{tabular}

Standard errors in parentheses.

a Average number of years of schooling.

*** Significant at $1 \% ; * *$ Significant at $5 \%$; ${ }^{*}$ Significant at $10 \%$.

OLS, ordinary least squares.

higher chance of finding a job after their treatment than participants who enter the programme in a low-unemployment period. This is consistent with the findings from, for instance, Kluve (2010), and Lechner and Wunsch (2009). Lechner and Wunsch (2009) show that 'all else equal', higher unemployment at time of inflow into (training) programmes correlates positively with the programmes' effects. ${ }^{3}$ However, even though our individual model corrects for some participant characteristics, we suspect that the positive relation between unemployment at time of inflow and the programme success is also driven by unobserved participant characteristics, which are more favourable when the pool of unemployed is large. Evidence of this is given in the discussion of Table 5.

With regard to educational background, the aggregate model shows that a higher-average educational attainment corresponds with a higher-average 
job finding rate, whereas the individual model that distinguishes between education levels shows no significant effect. The variable 'unemployment status' is a dummy variable that distinguishes participants who entered the WGP without having been formerly registered as unemployed (dummy $=0$, remember from Section 2.1 that these consist of women re-entering the labour force, early school-leavers and disabled) from those who had a registered unemployment history (dummy $=1)$. We observe that participants without a registered unemployment history have a higher chance of finding a job after the WGP. A possible explanation for this could be that these participants are more intrinsically motivated to get back to work (in the case of women re-entering the labour force because they make the deliberate choice to re-enter the labour force), and that they have not suffered from a discouraged worker effect.

Age and gender have no significant impact on the aggregate model or its robustness and were left out. However, the individual model shows that an increase in age has a negative effect on the chances of finding a job. Interacting age groups with the 'unemployment status dummy' shows that participants between age 31 and 40 have a higher chance of finding a job after the WGP than the reference group of 16- to 30-year-olds. Both the duration of unemployment and gender are not significant in the individual model. This suggests that the WGP is quite successful, given the intrinsic qualities of the candidates. ${ }^{4}$

\section{A Closer Look at the Inflow of the WGP}

To further investigate if higher unemployment leads to better qualified participants, we zoom in on the (dynamics of the) inflow quality in the WGP. In Table 4, we present the ordinary least square estimates of the effect of 'unemployment at time of inflow', gender and age on the quality of participants. ${ }^{5}$ The quality of participants is measured as the ratio of the participant's years of schooling to the labour force average years of schooling in the year of inflow. We constructed this ratio to correct for possible bias that might arise due to the rising trend in the labour force's overall education level. The first result we observe is that the higher the unemployment rate at time of inflow, the higher the educational attainment of participants entering the WGP. Whether this results from self-selection or selection by intermediaries/Philips cannot be answered with certainty. Albeit neither gratifying nor original to argue, it is most likely a combination of both. We also find that relative to participants from the age group of 16-30 years, participants from older age groups have a lower educational attainment relative to the labour force average. This is not surprising since recent generations stay in education longer, and hence the average educational attainment of the labour force has risen steadily during the last decades. Finally, we observe that female WGP participants appear to have a lower educational attainment. 
TABLE 4

Effect of Labour Market Conditions on Participants' Quality, 1987-2006

\begin{tabular}{lc}
\hline & Educational attainment $^{\text {a }}$ \\
\hline Unemployment at time of inflow & $0.04(0.00)^{* * *}$ \\
Gender: & Reference \\
$\quad$ Male & $-0.04(0.01)^{* * *}$ \\
Female & \\
Age groups: & Reference \\
16-30 years & $-0.02(0.01)^{* *}$ \\
31-40 years & $-0.04(0.01)^{* * *}$ \\
41-50 years & $-0.06(0.03)^{* *}$ \\
C50 years & $0.74(0.02)^{* * *}$ \\
Constant & 0.06 \\
$R^{2}$ & 6611 \\
\hline & \\
\hline
\end{tabular}

Standard errors in parentheses.

a Participant's years of schooling to labour force average years of schooling ratio.

*** Significant at $1 \%$; ** Significant at $5 \%$; $*$ Significant at $10 \%$.

By analysing the time participants spent in the WGP, we can provide an alternative analysis that more clearly shows the business cycle effect on the quality of inflow. As presented in the Appendix, our ' 8,900 dataset' contains a variable measuring the time spent in the WGP. This is measured as duration in months. A 'bread-and-butter' WGP treatment takes 12 months. Thus, when a person takes more than 12 months to complete, he or she apparently needs more time to be deemed ready for outflow and is likely to have been relatively less qualified at time of inflow (in Section 2.2, we already mentioned that less qualified participants are regularly offered a 6- or 12-month extension). Based on this assumption, we construct a dummy variable equal to ' 0 ' when participants spent at most 12 months in the WGP, and equal to ' 1 ' for participants who spent more than 12 months in the WGP (since an extension lasts a fixed 6 or 12 months, there is hardly any variation in the duration, so we used a dummy variable instead of actual duration in months). We tested the sensitivity of this dummy to the business cycle and the characteristics of the inflow with a probit model. Table 5 contains the results.

We observe that women are less likely to spend more than 12 months in the WGP and that the middle-aged participants are more likely to stay longer in the WGP than the youngest participants. Furthermore, both high-level vocational and university-educated participants are less prone to spend more than 12 months in the WGP. The business cycle effect manifests itself as the negative relation between unemployment at time of inflow and the duration dummy. When the labour market is tight and unemployment is low at time of inflow, participants have a higher chance of spending more than 12 months in the WGP and are likely to be less qualified. Thus, participants are 'lockedin' the WGP longer when unemployment was low at time of inflow. However, 
TABLE 5

Effect of Business Cycle and Inflow Characteristics on Time Spent in WGP, 1987-2006

\begin{tabular}{lc}
\hline & Duration dummy \\
\hline Unemployment at time of inflow & $-0.20(0.02)^{* * *}$ \\
Gender: & Reference \\
$\quad$ Male & $-0.40(0.05)^{* * *}$ \\
Female & \\
Age groups: & Reference \\
Age 16-30 & $0.12(0.05)^{* *}$ \\
Age 31-40 & $0.27(0.07)^{* * *}$ \\
Age 41-50 & $0.23(0.15)$ \\
Age 51+ & \\
Prior education: & Reference \\
Primary school & $0.08(0.07)$ \\
Low-level vocational & $-0.10(0.08)$ \\
Low-level secondary & $-0.05(0.07)$ \\
Middle-level vocational & $-0.16(0.11)$ \\
Middle-level secondary & $-0.17(0.16)$ \\
Top-level secondary & $-0.37(0.10)^{* * *}$ \\
High-level vocational & $-0.46(0.12)^{* * *}$ \\
University & $0.03(0.11)$ \\
Constant & $91.45 \%$ \\
Correctly specified by probit model & 6611 \\
$N$ & \\
\hline
\end{tabular}

Standard errors in parentheses.

*** Significant at $1 \%$;* Significant at $5 \% ; *$ Significant at $10 \%$.

our explanation (a person needs more time in the WGP to be qualified enough to successfully exit the WGP) differs from the usual explanation that 'locking-in' occurs due to reduced job search efforts on behalf of the participant. Thus, even though we correct for several significant participant characteristics, we still find that the unemployment rate at time of inflow matters for the duration spent in the WGP. This supports our impression from Table 3 that unobserved participant characteristics vary with the size of the pool of unemployed.

\section{Performance of the WGP}

We now turn to assessing the performance of the WGP. To assess the performance, we need to conduct a counterfactual analysis, that is, what would have happened - in terms of labour market outcome - to participants if they had not joined the WGP? To conduct such a counterfactual analysis, we apply the nearest neighbour matching technique - see Dehejia and Wahba (2002) for its theoretical validity.

We use data from the labour supply panel, which are collected biannually by the Netherlands Institute for Social Research since 1985. The labour supply panel is a representative sample of the Dutch labour force - see 
Fouarge et al. (2006). Since it is rotating, we can track respondents and trace changes in their labour market position. Information on gender, age, residence, unemployment duration and educational attainment is readily available. Moreover, this information is consistently available for the period for which we have information on WGP participants. We, therefore, decide to exploit this data to conduct the matching estimator analysis.

First, we need to establish the length of the period between the start of the WGP programme and the time at which the WGP participant is interviewed about his or her job finding success. We find that the mean treatment period for WGP participants is 12.6 months. The small standard error (0.19 months) indicates that variation in programme participation length is rather small. Consequently, we assume that every WGP participant will stay in the programme for 12.6 months. Since Philips interviews programme participants six weeks (equivalent to 1.4 months) after concluding the programme, the average time between starting programme participation and the job finding interview is 14 months. Therefore, to ensure accurate matching, we simulate this time window for our control group, that is, respondents from the labour supply panel exploiting retrospective information in the questionnaire. We conduct this procedure for the labour supply panels for the years 1994, 1996, 1998, 2000, 2002, 2004, 2006 and 2008 (using 2008 to establish transition rates only, discarding any panels prior to 1994) to collect a group of unemployed who can serve as a control group in our analysis. We ensure that the respondents from the labour supply panel can only enter once in our control group (we select the first entry and discard any subsequent entries).

We end up with a group of 384 unemployed who constitute our control group, while we have 780 WGP participants, who have been exposed to the treatment. Table 6 gives descriptive statistics of the variables we will use in our matching estimator. We note that WGP participants experience slightly longer uncompleted spells of unemployment, have slightly higher educational attainments, are concentrated in southern Netherlands, and are more likely male and younger. Finally, we note that the average job finding rate of WGP participants is higher.

To perform this matching estimator, we need to impose the number of matches (in the control group) for each treated respondent. This choice is a trade-off between the similarity of respondents in the control group to the treated respondents and robustness of the comparison. That is, a high number of required matches ensures robustness of the comparison, but we may start including control group respondents who are not that similar any more to the treated respondents as the nearest neighbours. We follow Abadie and Imbens (2002), and set the number of matches equal to four. Since the sample size of the treatment group is larger than the sample size of the control group, we also tried lower levels of required matches. Lower levels of required matches do not change our results in a significant manner. Finally, since we are testing the success of an existing programme, we present the sample average treatment effect. 
TABLE 6

Descriptive Statistics of Matching Variables (Mean Values)

\begin{tabular}{lcc}
\hline Matching variables & WGP participants & Non-WGP participants \\
\hline Unemployment duration: & & \\
6 months or less & 0.26 & 0.33 \\
6 months-1 year & 0.26 & 0.19 \\
1 year-2 years & 0.21 & 0.20 \\
$\quad$ More than 2 years & 0.26 & 0.28 \\
Educational attainment: & 0.08 & 0.11 \\
$\quad$ Primary school & 0.28 & 0.40 \\
Lower vocational & 0.37 & 0.28 \\
Middle vocational & 0.17 & 0.14 \\
Higher vocational & 0.10 & 0.08 \\
$\quad$ University & 0.22 & 0.16 \\
Spatial identifier: & 0.16 & 0.22 \\
$\quad$ Northern Netherlands & 0.01 & 0.36 \\
Eastern Netherlands & 0.62 & 0.26 \\
$\quad$ Western Netherlands & & \\
$\quad$ Southern Netherlands & 0.55 & 0.41 \\
Gender: & 0.45 & 0.59 \\
$\quad$ Male & 36.5 & 39.7 \\
Female & & \\
Age: & 0.55 & 0.39 \\
$\quad$ Average & & \\
Job finding rate: & After 14 months &
\end{tabular}

TABLE 7

Measuring WGP Treatment Effect Using Nearest Neighbour Matching Technique

\begin{tabular}{|c|c|c|}
\hline Matching variables & \multicolumn{2}{|c|}{ Sample average treatment effect } \\
\hline (1) Vacancy rate and year & $0.30^{* * *}$ & $(0.040)$ \\
\hline (2): (1) + unemployment duration & $0.29 * * *$ & $(0.041)$ \\
\hline (3): (2) + educational attainment & $0.31 * * *$ & $(0.037)$ \\
\hline (4): (3) + regional identifier & $0.29 * * *$ & $(0.038)$ \\
\hline (5): $(4)+$ gender & $0.23^{* * *}$ & $(0.040)$ \\
\hline$(6):(5)+$ age & $0.18^{* * *}$ & $(0.041)$ \\
\hline Sample size (WGP participants) & \multicolumn{2}{|c|}{$1,164(780)$} \\
\hline
\end{tabular}

Standard errors in parentheses.

*** Significant at 1\%; ** Significant at 5\%; ${ }^{*}$ Significant at $10 \%$.

Table 7 contains the results, in which we progressively add matching variables. We start with the vacancy rate (to control for business cycle differences overtime) and year dummies (to control for potential institutional changes throughout the time window). Adding more matching variables to the matching procedure gives some expected effects:

- Programme participants are more often male, which in those years made them more employable, ceteris paribus, lowering the treatment effect.

- Programme participants are younger, which made them more employable, ceteris paribus, lowering the treatment effect. 
Once we include the complete set of control variables, we note a statistically significant positive average treatment effect of 0.18 . Since our outcome variable is (0) unsuccessful in finding employment and (1) successful in finding employment, the coefficient is the percentage point difference to find employment between participation and non-participation in the WGP programme. Consequently, we find that the WGP lifts the job finding rate of participants by 18 percentage points.

The above analysis refers to the persons in the control group who may have benefited from public treatment programmes other than (public) employment, such as job search assistance, job counselling and training. Groot et al. (2008) show that if public reintegration treatment for unemployed persons is started in the first year, the job finding probability within 1.5 years increases by 0.9 percentage points. This implies that our finding of an increased probability of finding a job of 18 percentage points due to participation in the WGP is not seriously affected by the composition of the control group with respect to participation in a reintegration programme. It also implies that the impact of the WGP is much larger than the impact of participating in a public reintegration programme - see also the discussion in the Introduction.

\section{What are the benefits to the firm?}

There are a number of possible benefits to the firm running a private employment programme. The first possible benefit to the firm is that the WGP might serve as a fruitful recruitment channel. Table 8 provides some quantitative evidence that supports this notion.

We constructed a subset of participants who found a job after their WGP treatment, and added a dummy with value ' 1 ' if this was a job with Philips, or a value of ' 0 ' for a job elsewhere. This allows us to identify which type of participants Philips favours to offer a regular job. In terms of independent variables, we use a similar structure as in Table 3.

We find that the unemployment rate at time of inflow negatively correlates with employment prospects at Philips. To understand this finding, we need to go back to Figure 4, which among others depicts the share of participants who find a job at Philips over time. We note that this share is fairly stable (especially for the 1999-2007 period, which is the relevant time window for the regression above), while the share of participants who find employment elsewhere fluctuates heavily. We, therefore, assume that Philips has a policy of recruiting a stable share of WGP participants. We know from Tables 4 and 5 that if unemployment at time of inflow is high, participants have higher educational levels and experience lower unemployment duration. Consequently, they should have better job prospects regardless of programme participation. Therefore, the share of participants who find a job elsewhere (i.e. not with Philips) will increase when the unemployment rate at time of inflow increases. This, in turn, implies that the share of participants who find 
TABLE 8

Who Stay with Philips? 1999-2007

\begin{tabular}{lcc}
\hline & \multicolumn{2}{c}{ Job with Philips } \\
\hline National level: & & \\
Unemployment at time of outflow & 0.02 & $(0.14)$ \\
Unemployment at time of inflow & $-0.26^{*}$ & $(0.14)$ \\
Age & -0.02 & $(0.01)$ \\
Gender & -0.04 & \\
Prior Education: & & \\
Primary school & Reference \\
Low-level vocational/secondary & $0.56^{*}$ & $(0.29)$ \\
Middle-level vocational/secondary & $0.50^{*}$ & $(0.28)$ \\
High-level vocational & 0.19 & $(0.31)$ \\
University & $0.80^{* * *}$ & $(0.31)$ \\
Unemployment status & -0.19 & $(0.20)$ \\
Unemployment duration (if unemployed): & & \\
0-6 months & Reference & $(0.18)$ \\
6-12 months & 0.14 & $(0.22)$ \\
12-24 months & -0.24 & $(0.22)$ \\
24-48 months & -0.03 & $(0.25)$ \\
48+ months & -0.07 & \\
Age group (if unemployed): & & $(0.22)$ \\
Age 16-30 & Reference & $(0.33)$ \\
Age 31-40 & 0.20 & $(0.47)$ \\
Age 41-50 & 0.26 & $(0.59)$ \\
Age 51+ & $0.93^{* *}$ & \\
Constant & 0.00 & 552 \\
Sample size & & \\
\hline
\end{tabular}

Standard errors in parentheses.

*** Significant at $1 \%$;* Significant at $5 \%$; * Significant at $10 \%$.

a job with Philips in total participants who find a job decreases when the unemployment rate at time of inflow increases.

Further, we note that Philips is less likely to employ participants whose highest level of education is primary school. Other variables, including age, gender and unemployment duration, do not play a major role in the firm's decision to recruit participants subsequent to programme completion. Consequently, Philips uses educational attainment to select participants for postprogramme employment, whereas age, gender and unemployment duration play only minor roles. Obviously, since Philips is able to monitor participants for a year, it may use other indicators (such as motivation) that remain unobserved in our analysis.

Another benefit is that running a private programme for unemployed fits perfectly in today's era of corporate social responsibility, and as such brings the firm some positive externalities. This proposition was featured, among others, in a questionnaire we sent to 69 human resource managers of Philips in Netherlands. We asked to what extent corporate social responsibility, the added recruitment channel and improved union relations are perceived as reasons why Philips runs the WGP. The results are summarized in Table 9, which shows that the distribution for all three reasons is left-skewed. 
TABLE 9

Reasons Important to Run the WGP

\begin{tabular}{lccccc}
\hline & $\begin{array}{c}\text { Very unimportant } \\
(\%)\end{array}$ & $\begin{array}{c}\text { Unimportant } \\
(\%)\end{array}$ & $\begin{array}{c}\text { Neutral } \\
(\%)\end{array}$ & $\begin{array}{c}\text { Important } \\
(\%)\end{array}$ & $\begin{array}{c}\text { Very important } \\
(\%)\end{array}$ \\
\hline $\begin{array}{c}\text { Corporate social } \\
\text { responsibility }\end{array}$ & 0 & 0 & 3 & 27 & 70 \\
$\begin{array}{c}\text { Added } \\
\text { recruitment } \\
\text { channel }\end{array}$ & 6 & 18 & 18 & 48 & 9 \\
$\begin{array}{c}\text { Improved union } \\
\text { relations }\end{array}$ & 15 & 9 & 39 & 33 & 3 \\
\hline
\end{tabular}

$N=33$.

This suggests that the WGP benefits the firm in terms of showing corporate social responsibility, improved unions relations and an added recruitment channel, underscoring the finding from Table 8. Especially in the Netherlands, with its culture of centralized wage bargaining, the value of good union relations is vital. A last benefit of this programme is that it is used to dampen productivity losses through the so-called combi-project. This means that the participant can temporarily replace a regular employee at times when the latter is away for training. This also implies that the work experience that the participant gets is as close to regular as can be.

\section{Concluding remarks}

The article explored whether a pure private employment programme is beneficial to both unemployed workers and firms. To this end, we analysed the effectiveness of a large Dutch firm's employment programme: the Philips Employment Scheme (WGP). We find an average treatment effect of 18 per cent, which means that the average programme participant has an 18 percentage point higher job finding probability than an unemployed person who did not participate in the programme, but otherwise similar characteristics. The private programme uses a carefully designed selection process, in which the focus on the unemployed who need the treatment most is securely anchored. Additionally, the treatment itself entails various private components, of which the relative effectiveness has already been established in the literature and confirmed by this article. The most important of these is that the work experience gained during the treatment resembles a regular job as closely as possible, which provides a direct way of signalling one's capabilities to future employers. Interesting from both a business and policymaker's perspective is that running a private employment programme also brings benefits to the firm. Evidence presented in Section 5 shows that the programme serves as a fruitful recruitment channel, contributes to the firm's image of corporate social responsibility, helps improve union relations 
and can dampen productivity losses that occur when regular staff receive off-the-job training.

Final version accepted on 15 July 2012.

\section{Acknowledgements}

We thank Lex Borghans, Didier Fouarge, Joop Hartog, Hans Heijke, Morris Kleiner, Ben Kriechel and two anonymous referees for their helpful comments and insights. We thank Philips Electronics Netherlands for providing us access to the data. We also thank the participants of the following conferences and seminars for their questions, comments and insights: The Society of Labor Economists Conference (Boston, USA, 2009), the Centre of Full Employment and Equity Conference (Newcastle, Australia, 2009), the Society of Heterodox Economists Conference (Sydney, Australia, 2009), the European Society for Population Economics Conference (Essen, Germany, 2010), the James Cook University School of Business Seminar (Townsville, Australia, 2009), the Netherlands Network of Economics Day (Utrecht, the Netherlands, 2010), and the Lifelong Learning Conference (Eindhoven, the Netherlands, 2010).

\section{Notes}

1. See, for instance, Kluve (2010) and Card et al. (2009) for meta-studies confirming this, or Jaenichen and Stephan (2009), Sianesi (2008), Graversen and Jensen (2010), and Carling and Richardson (2004) for micro-econometric evaluation studies confirming this.

2. An exception to this rule was made for three groups: women re-entering the labour market, early school-leavers and the disabled.

3. One explanation they provide is that in times of high unemployment, nonparticipants experience fewer job matches or worse matches than when unemployment is low, and this reflects negatively on their future prospects, whereas programme participants enjoy a stable programme situation and do not incur unfavourable matches.

4. We tested this model on several levels of geographical aggregation for unemployment - that is, also looking at regional and municipal unemployment. However, the results remain qualitatively the same.

5. Again, we also looked at various levels of geographical aggregation for unemployment, and again we found qualitatively the same results.

\section{References}

Aakvik, A., Heckman, J. and Vytlacil, E. (2005). 'Estimating treatment effects for discrete outcomes when responses to treatment vary: an application to Norwegian vocational rehabilitation programs'. Journal of Econometrics, 125 (1): 15-52.

(C) John Wiley \& Sons Ltd/London School of Economics 2012. 
Abadie, A. and Imbens, G. (2002). 'Simple and Bias-Corrected Matching Estimators for Average Treatment Effects'. NBER Technical Working Papers, No. 283, Cambridge, MA: NBER.

Card, D., Kluve, J. and Weber, A. (2009). 'Active Labor Market Policy Evaluations: A Meta-Analysis (March 1, 2009)'. CESifo Working Paper Series, No. 2570; Ruhr Economic Paper No. 86. Available at SSRN, http://ssrn.com/abstract=1356534

Carling, K. and Richardson, K. (2004). 'The relative efficiency of labor market programs: Swedish experience from the 1990s'. Labour Economics, 11 (3): 335-54.

CPB (2009). Macroeconomic Outlook 2009. The Hague: CPB.

Dehejia, R. and Wahba, S. (2002). 'Propensity score-matching methods for nonexperimental causal studies'. Review of Economics and Statistics, 84 (1): 151-61.

Fouarge, D., Gielen, A., Grim, R., Kerkhofs, M., Roman, A., Schippers, J. and Wilthagen, T. (2006). Trendrapport aanbod van arbeid 2005, OSA A220.

Gerards, R., Muysken, J. and Welters, R. (2010). 'Active labour market policy by a profit maximizing firm'. Meteor Research Memorandum, No. 10/042, Meteor, Maastricht.

Gerfin, M., Lechner, M. and Steiger, H. (2005). 'Does subsidised temporary employment get the unemployed back to work? An econometric analysis of two different schemes'. Labour Economics, 12 (6): 807-35.

Graversen, B. (2004). 'Employment Effects of Active Labour Market Programmes: Do the Programmes Help Welfare Benefit Recipients to Find Jobs?' PhD. Thesis, Aarhus Universitet, Institut for Økonomi.

- and Jensen, P. (2010). 'A reappraisal of the virtues of private sector employment programmes'. Scandinavian Journal of Economics, 112 (3): 546-69.

Groot, I., Graaf-Zijl, M., Hop, J., Kok, L., Fermin, B., Ooms, D. and Zwinkels, W. (2008). De lange weg naar werk: beleid voor langdurig uitkeringsgerechtigden in de $W W$ en de $W W B$. Den Haag/Amsterdam/Hoofddorp: RWI/SEO Economisch Onderzoek/TNO.

Jaenichen, U. and Stephan, G. (2009). 'The effectiveness of targeted wage subsidies for hard-to-place workers'. Applied Economics, 43 (10): 1209-25.

Kluve, J. (2010). 'The effectiveness of European active labor market programs'. Labour Economics, 17 (6): 904-18.

Lechner, M. and Wunsch, C. (2009). 'Are training programs more effective when unemployment is high?' Journal of Labor Economics, 27 (4): 653-92.

Martin, C. and Swank, D. (2004). 'Does the organization of capital matter? Employers and active labor market policy at the national and firm levels'. American Political Science Review, 98 (4): 593-611.

Martin, J. and Grubb, D. (2001). 'What works and for whom: a review of OECD countries' experiences with active labour market policies'. Swedish Economic Policy Review, 8 (2): 9-56.

Sianesi, B. (2008). 'Differential effects of active labour market programs for the unemployed'. Labour Economics, 15 (3): 370-99.

van der Bruggen, T. (2004). 'De lange weg naar Den Haag'. Eindhoven: Lecturis. and van Schagen, J. (2001). 'Met het oog op de arbeidsmarkt: ervaringen met het Philips werkgelegenheidsplan'. Philips Electronics, Nederland.

Welters, R. (2005). 'Efficiency of Employment Subsidies and Firms' Recruitment Strategies'. PhD Thesis, Maastricht University. 


\section{Appendix: Data on Individuals in the WGP}

In this article, we use three datasets. One dataset was based on yearly aggregates as summarized in Table 1 and two datasets with individual data. We describe the two latter datasets in this Appendix. The first dataset contains data on 8,928 individual participants of the WGP. This dataset was originally extracted from Philips' administrative systems and is the most integral collection of WGP participants available, containing 75 per cent of all WGP participants ever. On the other hand, we obtained data on 1,038 former WGP participants surveyed six weeks after the end of their WGP treatment in the period 1997-2007. Both datasets are described briefly below.

\section{'8,900 Dataset'}

This large sample size comes with a trade-off since the information we have per participant is limited to a number of 'bread-and-butter' variables. Table A1 summarizes the most important variables in this dataset. Looking at the various statistics in the table, especially the means and standard deviations, we can state that the WGP inflow is quite heterogeneous. Moreover, although this was never recorded accurately enough to be used as a variable, we know from working with the data and from qualitative sources that there is also a large variation in ethnicity of participants. The level of prior education was originally defined in eight categories specific to the Dutch education system. Table A2 provides the number of WGP participants from each educational background. For later analysis, we translated these categories into 'years of school' as shown in the last column.

\section{'Questionnaire Dataset'}

The most detailed information on individuals who have participated in the WGP comes from the 'questionnaire dataset'. This dataset stems from Philips

TABLE A1

Summary of Main Variables '8,900 Dataset'

\begin{tabular}{lccccr}
\hline Variable $(N=8928)$ & $N$ & Mean & Standard deviation & Min & Max \\
\hline $\begin{array}{l}\text { Start-year of WGP } \\
\quad \text { reatment }\end{array}$ & 8928 & & & 1983 & 2009 \\
$\begin{array}{l}\text { End-year of WGP } \\
\quad \text { rreatment }\end{array}$ & 8712 & & & 1983 & 2009 \\
$\begin{array}{l}\text { Duration of WGP } \\
\quad \text { reatment (months) }\end{array}$ & 8712 & 10.0 & 4.5 & 0 & 24 \\
$\begin{array}{l}\text { Age } \\
\text { Level of prior education } \\
\quad(\text { years of school) }\end{array}$ & 8928 & 28.5 & 8.2 & 16 & 60 \\
$\quad$ & $N$ & Male & Female & 6 & 16 \\
$\begin{array}{l}\text { Gender } \\
\text { Residential address }\end{array}$ & 8928 & 5187 & 3741 & & \\
\hline
\end{tabular}


TABLE A2

Prior Education Level of WGP Participants

\begin{tabular}{llccc}
\hline Prior education & $N$ & $\%$ & Years of school \\
\hline LO (primary school) & LO + LBO: Primary & 1280 & 17.9 & 6 \\
LBO (low-level vocational) & MAVO - VWO: Secondary & 1581 & 22.1 & 9 \\
$\begin{array}{l}\text { MAVO (low-level } \\
\quad \text { secondary) }\end{array}$ & 1322 & 14.3 & 10 \\
$\begin{array}{l}\text { MBO (middle-level } \\
\quad \text { vocational) }\end{array}$ & 1302 & 18.2 & 10.5 \\
$\begin{array}{l}\text { HAVO (middle-level } \\
\quad \text { secondary) }\end{array}$ & 466 & 6.5 & 11 \\
$\begin{array}{l}\text { VWO (top-level secondary) } \\
\text { HBO (high-level } \\
\quad \text { vocational) }\end{array}$ & HBO + WO: Tertiary & 183 & 2.6 & 12 \\
WO (university) & & 813 & 11.4 & 15 \\
\hline
\end{tabular}

databases in which the returned questionnaires are stored. It contains the answers of 1,038 former WGP participants surveyed six weeks after the end of their WGP treatment. We observe 1,038 participants since we could only retrieve the individual questionnaires sent out in the years 2000-2007. This includes persons who started their WGP treatment in 1997 and ended it in 1999. The average response to the questionnaire was 59 per cent. Table A3 summarizes the main variables.

The substantial variations in age, prior education and unemployment duration confirm the heterogeneity of participants observed in Table A1. In addition to the variables reported in the table, the 'questionnaire dataset' contains data on participant satisfaction with the WGP treatment, and answers to questions that enquire about the intensity of supervision participants received from both Philips and the Labour Office.

In Gerards et al. (2010), we show that this can be considered a representative sample of the large ' 8,900 dataset', as it displays very similar movements in gender and age composition of participants. Due to differences in how prior education was defined in both datasets, we could not construct a reasonable comparison of this characteristic (even though we managed to translate them both into 'years of education'). In the ' 8,900 dataset', prior education was classified in eight levels, whereas the classification in the 'questionnaire dataset' contained only five levels. Especially, the lower education levels were more compressed into aggregates in the 'questionnaire dataset', leading to less accuracy there. 


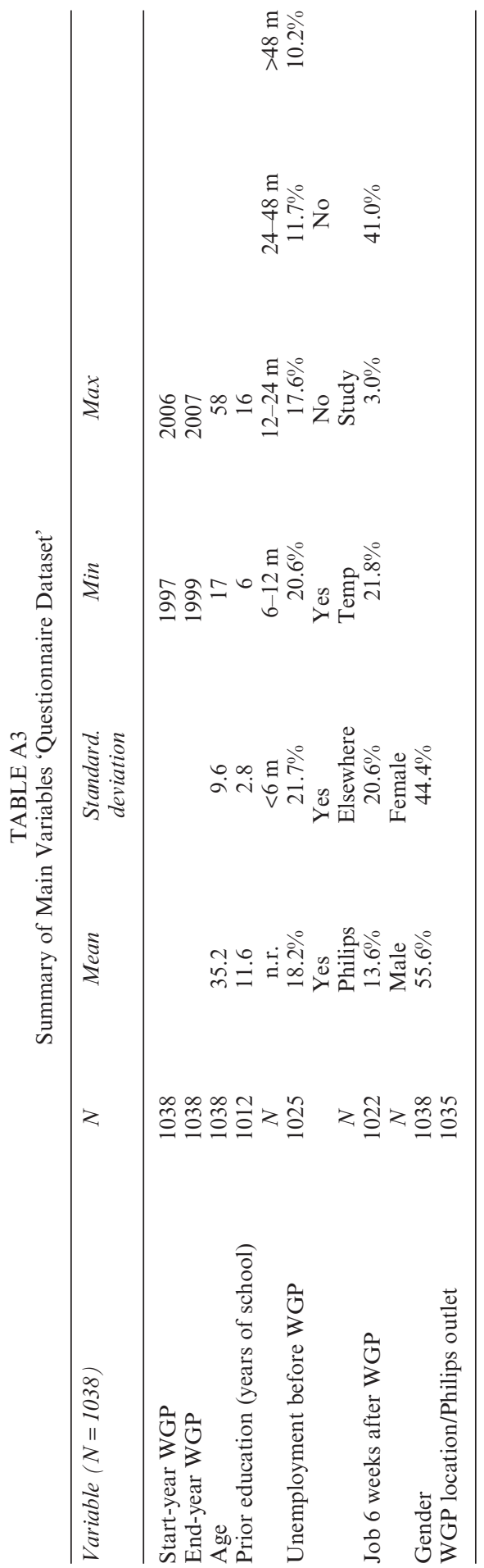

